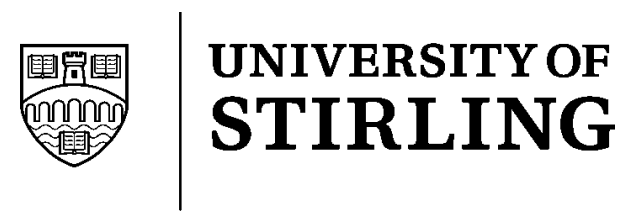

\title{
Assessing the potential impact of lease accounting reform: a review of the empirical evidence
}

\author{
ALAN GOODACRE \\ Dept. of Accounting, Finance and Law \\ University of Stirling, Stirling FK9 4LA \\ Tel: 01786467291 \\ Fax: 01786467308. \\ e-mail: Alan.Goodacre@stir.ac.uk
}

Running title: Potential Impact of Lease Accounting Reform

This paper was presented at the RICS Cutting Edge 2001 Conference, Oxford. 


\title{
Assessing the potential impact of lease accounting reform: a review of the empirical evidence
}

\begin{abstract}
Summary
Accounting standard-setters have proposed that the right to use assets (including land and buildings) acquired under operating lease contracts should be recognised on the balance sheet of lessee companies. In recent years, several empirical research studies have investigated the potential impact of the proposed changes in accounting for leases. The current paper reviews this work and presents some new evidence, for a property audience.
\end{abstract}

The paper summarises evidence that operating leases represent a major source of finance for many companies generally, and more specifically for companies in the retail sector. Recognition of operating leases on the lessee's balance sheet would have a significant impact on performance measures, especially gearing. If markets are informationally 'efficient' such changes should have little impact. However, research evidence on efficiency with respect to lease accounting information is mixed. What's more, company managers do not believe that the market is efficient so are likely to behave as if the markets are 'inefficient'. Possible reactions include reduced use of leasing, shorter lease contract terms, more break clauses, or increased use of contingent rental agreements. It seems likely that lessors will be under pressure to bear greater risks.

Keywords: leases, accounting, SSAP21, G4+1, gearing, off-balance sheet finance, retail 


\section{Assessing the potential impact of lease accounting reform: a review of the empirical evidence}

\section{Introduction}

The rights to use assets (including land and buildings) acquired under operating lease contracts are not currently recognised on the balance sheet of UK companies; rather, aggregate information about such contracts is disclosed by way of a note to the financial statements. Since the implementation in 1984 of the current UK lease accounting standard SSAP21 (ASC, 1984), offbalance sheet operating leases have grown considerably, at the expense of on-balance sheet finance leases; Figure 1 illustrates this growth. Two discussion papers by the G4+1 group of accounting standard-setters ${ }^{1}$ have addressed the issue of off-balance sheet leases and the more recent of these proposes that all leases should be recognised on the balance sheet. ${ }^{2}$ As already recognised by the Investment Property Forum, this is an important issue for those involved in the property sector as a large proportion of the value of leases currently classified as operating leases relate to land and buildings (Investment Property Forum, 1999). In recent years, several empirical research studies have investigated the potential impact of the proposed changes in accounting for leases. The aim of the current paper is to summarise and review this research and some new evidence, for a property audience.

\section{$<$ Figure 1 about here >}

\section{Accounting for leases: current and proposed}

SSAP 21 identifies two types of lease and requires a radically different accounting treatment for each. A lease that transfers to the lessee substantially all the risks and rewards of ownership is a finance lease and is treated as an 'in substance' purchase by the lessee and sale by the lessor. Accordingly, an asset is shown on the lessee's balance sheet at the present value of the minimum lease payments and a corresponding liability is recognised. On the other hand, a lease which does not transfer substantially all the risks and rewards of ownership to the lessee is deemed to be an operating lease. Under an operating lease the full value of the leased item is treated as an asset of the lessor and the lessee simply recognises the rental payments as an expense, with limited additional footnote disclosure of future lease rental commitments. Internationally, other existing leasing standards such as International Accounting Standard 17, and Statement of Financial Accounting Standard 13 in the US, are based on similar concepts to SSAP 21 in relation to distinguishing finance leases from operating leases. In most circumstances, commercial property rented by UK businesses will be classified as operating leases since the lessor retains, to a greater or lesser extent, the risks and rewards of ownership. Thus, most rented properties do not feature in the tenants' balance sheets.

In recent years, accounting has seen a shift in focus towards a balance sheet approach, in which assets and liabilities are defined and criteria are set out for their recognition and measurement. This focus represents a fundamental shift away from the traditional 'matching' of income with related expenditure in the profit and loss account, and means that the measure of periodic income becomes more of a residual in the accounting process. The definitions of assets and liabilities are key features of this approach and underpin the development of accounting standards. Assets are defined as 'rights or other access to future economic benefits controlled by an entity as a result of past transactions or events'; liabilities are 'obligations of an entity to transfer economic benefits as a result of past transactions or events' (ASB, 1999b). In light of these definitions, most lease transactions, including those which SSAP21 would categorise as operating leases, are likely to give rise to an asset and liability for the lessee. However, until explicitly withdrawn by the standard-setters, SSAP21 continues to apply. 
This change in accounting focus provides the background for the developments in accounting for leases. In 1996, the G4+1 published a special report entitled Accounting for Leases: A New Approach (McGregor, 1996). This identified several fundamental deficiencies in current lease accounting standards. First, they omit material assets and liabilities arising from 'off-balance sheet' operating lease contracts. Second, marginal differences in contractual terms can result in one lease being claimed as a finance lease and another as an operating lease and thus similar transactions do not receive the same accounting treatment. Third, the 'all or nothing' approach to the capitalisation of leased assets does not adequately reflect modern complex transactions. The report went on to explore a conceptual approach to lease accounting, recommending that new standards should be developed that would remove the distinction between finance leases and operating leases and would require lessees to recognise as assets and liabilities all material rights and obligations arising under lease contracts.

More recently, the UK Accounting Standards Board (ASB) published a discussion paper Leases: Implementation of a New Approach (ASB, 1999a), in which the G4+1 develops the approach recommended in the special report. The discussion paper recommends that all leases should be reflected in financial statements in a consistent manner and it explores the principles that should determine the extent of the assets and liabilities that lessees and lessors would recognise under leases. In particular, it argues that conceptually the right to use an item of property for the lease term (rather than the physical item itself) is an asset of the lessee. Similarly the lessee's obligation to make lease rental payments is a liability. Under the recommended approach, at the beginning of a lease the lessee would recognise an asset and a liability equivalent to the fair value of the rights and obligations that are conveyed by the lease (usually the present value of the minimum payments required by the lease). Thereafter, the accounting for the lease asset and liability would follow the normal requirements for accounting for fixed assets and debt. The lessor would report financial assets (representing amounts receivable from the lessee) and residual interests in the property as separate assets.

Several features of commercial property leases create difficulties for accountants; in particular, break clauses, renewal options, contingent rentals and rent reviews. For example, if a lease contains a break clause, should the lessee's liability be based on rentals up to the break point or to the end of the lease term? The general principle that the G4+1 discussion paper adopts is that the exercise of options (e.g. renewal or purchase options) should not usually be anticipated. Rather the option itself should be valued and recorded separately, if material. Thus, the discussion paper suggest that only payments up to the next break date should be included, since the payments beyond that data can be avoided by the lessee. However, in circumstances where the lessee effectively has to occupy or possess the property for the longer term, this will be deemed to be the minimum lease term.

As far as contingent rentals (based on usage or turnover/profit) are concerned, the proposal is that only the base rental should be valued. The contingent element should not be anticipated unless the minimum lease payments are clearly unrepresentative of the value of property rights conveyed by the lease. The fair value of property rights, argues the discussion paper, can be estimated by comparison with a similar lease having no provision for contingent rentals.

Most long-term property leases in the UK contain provision for regular 'upward-only' rent reviews. The G4+1 argues that, since the future rent increases cannot be avoided by the lessee, the increases should be estimated at the beginning of the lease contract and incorporated in the asset/liability value of the lease. ${ }^{3}$ However, the UK accounting standard-setting body dissents from this view because, it argues, it will often not be possible to make reliable estimates of the effect of such increases (ASB, 1999a, p. 4). The ASB prefers that only existing rentals should form the basis of the lease asset/liability and that adjustments should be made at the time of rent reviews. 
Finally, the need to separately account for any service element in lease contracts, such as repairs, maintenance and insurance is confirmed in the discussion paper. Thus, as required under present lease accounting standards, the services element will not form part of the capitalised lease asset but will be charged as an expense by the lessee as incurred. However, this will impose a new requirement to split operating lease rentals for properties such as serviced offices between service and property components. The discussion paper does not go into any detail concerning how this split might be carried out, but two possible approaches can be envisaged. First, the information might be available from the lessor. Such information will be needed by the lessor to split out the property component of the rental to compute the two balance sheet elements for the property (future amounts receivable from the lessee and the residual interest) and to identify the service element to be recognised as profit annually. However, the landlord might be reluctant to disclose such commercially sensitive information to tenants. Alternatively, a comparison with lease rentals for office space without services could provide the basis for estimating the split into components.

\section{Impact of operating lease capitalisation on lessees' financial statements}

Company financial statements will be affected in several ways by the proposed new accounting treatment of leases. Table 1 illustrates the changes for a simplified hypothetical lessee company that leases a retail outlet for a term of 5 years with lease rentals of $£ 250 \mathrm{k}$ payable annually in arrears. The present value of the lease rentals is $£ 1,000 \mathrm{k}$ (implicit interest rate of $7.93 \%$ ). The first column of Panel A shows the balance sheet at 31 December 2000 assuming that the lease is treated as an operating lease; balance sheets for 2001 through 2005 would be identical. The remaining columns show balance sheets for each of the five years assuming that the lease is capitalised. The first column of Panel B shows the profit and loss account assuming operating lease treatment; the second column shows the incremental effect of capitalising the lease for the first year, and the remaining columns show the profit and loss accounts for each year assuming capitalisation. Three performance ratios are also calculated and given at the foot of the balance sheets and profit and loss accounts.

\section{< Table 1 about here >}

In the balance sheet at 31 December 2000, fixed assets will increase by the capitalised operating lease asset $(£ 1,000 \mathrm{k})$, and liabilities will also increase by the present value of the rental payments, split between the short-term portion due within one year $(£ 171 \mathrm{k})$ and the longer-term portion ( $£ 829 \mathrm{k}$ ). Initially the net debt to equity gearing ratio will jump from $40 \%$ to $140 \%$. Subsequent balance sheets will reflect the declining net book value of the fixed asset and the reduction in lease liability as 'capital' is repaid. Shareholders' equity (retained profit) will be changed by the cumulative profit and loss effect of capitalisation.

In the profit and loss account the full operating lease rental (OLR) payment of $£ 250 \mathrm{k}$ is presently charged against operating profit as a tax-deductible expense. Under the proposals, depreciation on the operating leased asset will be charged against operating profit and the interest element of the OLR will be included under interest charges. Depreciation would be a constant $£ 200 \mathrm{k}$ per annum, assuming straight-line depreciation, to write off the asset value over the life of the lease (presumed to be shorter than the useful life of the asset). Interest would be $£ 79 \mathrm{k}$ in the year to 31 December 2001 , declining to $£ 19 \mathrm{k}$ in year five. The impact is that, every year, EBITDA (earnings before interest, tax, depreciation and amortisation) will be higher by $£ 250 \mathrm{k}$ as the OLR will not be charged against EBITDA. Operating profit will also increase by £50k (since depreciation < OLR) in each of the five years.

Profit before tax will be lower in the early years of a lease, (depreciation + interest $>$ OLR) and higher in the later years as the interest element of OLR declines (depreciation + interest $<$ OLR). For example, in 2001, depreciation ( $£ 200 \mathrm{k})$ plus interest ( $£ 79 \mathrm{k})$ exceeds OLR ( $£ 250 \mathrm{~m})$ by $£ 29 \mathrm{k}$, so profit before tax will reduce by this amount. By contrast, in 2005, depreciation plus interest 
has fallen to $£ 219 \mathrm{k}$ and is lower than OLR, so profit before tax will actually increase by $£ 31 \mathrm{k}$. Under current tax rules, the amount of tax paid will be unchanged, so in this simplified example the changes in profit after tax (and retained profit) are identical to the changes in profit before $\operatorname{tax}^{4}$

Over the five-year period the total profit after tax will be the same $(£ 600 \mathrm{k})$ and is independent of the accounting treatment of the lease; the issue is how profit should be allocated to the individual accounting periods. Similarly, there is no change in annual cash flow. However, the balance sheet does change significantly depending on the choice between recognition of the asset and liability on-balance sheet and disclosure of information (off-balance sheet).

The impact on performance measures is clearly illustrated. The gearing measure (net debt/equity) initially increases fairly dramatically and then declines back to its original level by the end of 2005. This reflects, perhaps more realistically, the level of financial risk that results from the company's commitment to make future rental payments. Operating (and EBITDA) margins will maintain a higher level under lease capitalisation; in the example, the operating margin increases from $6.7 \%$ to $8.3 \%$. The impact on return on capital employed (ROCE) varies according to the balance between the respective impacts on profit and on capital employed. In the illustration, ROCE decreases initially because the increase in capital employed dominates the increase in operating profit; however, from 2003 onwards, capital employed has reduced somewhat to give a net increase in ROCE.

\section{How important are operating leases?}

Several studies have investigated the importance of operating lease capitalisation. Imhoff, Lipe and Wright (1991) developed a method for the constructive capitalisation of operating leases and used this to estimate the impact of capitalisation on two ratios (return on assets and debt to equity) for 14 US companies (seven matched pairs, selected to represent high and low operating lease use). They found that capitalisation would give rise to material differences in the ratios for both 'high' and 'low' lessees. A subsequent paper explored income effects of operating lease capitalisation and found that the effects can be both substantial and unpredictable in direction (Imhoff, Lipe and Wright, 1997). The retail investment analyst team at Dresdner Kleinwort Benson produced a research report highlighting the high level of gearing that would result from capitalising operating leases (Dresdner Kleinwort Benson, 1998). This was based on a detailed study of 27 large UK general retail companies and showed that 'net debt would be in excess of $100 \%$ of equity market capitalisation in many cases, .... exposing shareholders to extremely volatile returns'. While these studies were based on small samples, two recent UK studies have used more representative samples.

These two empirical studies used a similar approach, involving the 'constructive capitalisation' of operating lease assets and liabilities based on the footnote disclosure in companies' financial statements. The estimated value of lease asset and liability is calculated as the present value of minimum lease payments. This requires an estimate of the average lease term, remaining lease life and an appropriate discount rate for each company. The first study (Beattie, Edwards and Goodacre, 1998) used a random sample of 232 non-financial UK companies based on data for the period 1990-94. The second (Goodacre, 2001) used 1994-99 data for all 102 companies in the UK retail sector, a sector identified as likely to be a heavy user of operating lease finance. A comparison between the long-term element of operating leases and long-term debt is presented in Figures 2 and $3 .^{5}$

\section{<Figure 2 about here>}

For 1994 , the mean operating lease liability across all sectors was estimated to be $£ 51 \mathrm{~m}$, of which $£ 8 \mathrm{~m}$ was due within 1 year and $£ 43 \mathrm{~m}$ was long-term. This compared with on-balance sheet long-term debt of $£ 108 \mathrm{~m}$. The broad services sector was identified as a major user of operating lease finance with a mean total liability of $£ 127 \mathrm{~m}$. A clearer picture emerges by 
calculating the ratio of operating lease to debt finance, as summarised in Figure 3 . This demonstrates that, overall, operating leases represented $39 \%$ of on-balance sheet debt, but $54 \%$, $14 \%$ and $69 \%$ respectively for the consumer goods, general industrial and services sectors.

\section{$<$ Figure 3 about here>}

In the retail sector overall for 1999 , the mean operating lease liability was estimated to be $£ 234 \mathrm{~m}$, of which $£ 12 \mathrm{~m}$ was due within 1 year and $£ 222 \mathrm{~m}$ was long-term. This compared with on-balance sheet long-term debt of $£ 67 \mathrm{~m}$. The ratio of operating lease to debt finance was $332 \%$ overall, and $158 \%$ in food retailing and $512 \%$ in general retailing. Thus operating lease finance represents a major source of finance in the UK particularly for the services sector, and for retail companies within that sector. By contrast, finance leases were comparatively unimportant: operating lease liabilities were found to be 13 times (37 times) the level of finance lease liabilities across all sectors (retail companies).

The related off-balance sheet operating lease assets were approximately $6 \%$ and $28 \%$ of the onbalance sheet assets across all sectors and in the retail sector, respectively. Thus a significant proportion of UK companies' assets do not appear on their balance sheets. 'Land and buildings' is, by far, the major asset category financed by operating leases, representing $80 \%$ by value across all sectors and $98 \%$ in the retail sector. Capitalisation of operating leases would also have a significant impact on reported profit levels. In the retail sector, operating profit would increase by $23 \%$, on average; profit after tax would fall by approximately $7 \%$.

The observation that retail companies employ high levels of operating leases to finance (mainly) land and buildings assets is consistent with a priori expectations. Typically, the assets are fairly 'standard' (i.e. not firm-specific) and so can be transferred to alternative use (or users) at the end of the lease. Further, the growth in 'out-of-town' shopping in the UK, coupled with restrictions on developments has led to demand for such sites generally exceeding supply. Thus, the lessors' 'residual value' risk (including the residual value of the asset, and the costs of disposal or reletting, at the end of the lease) can be relatively low, making such assets attractive to lessors. In turn, any benefits can be passed on, at least partially, to the lessees. More recently, perhaps, retailers have opted to 'outsource' property provision to enable management to focus on their core skill of retailing and also to release funds for expansion or brand investment.

Companies' performance is often measured using key ratios such as operating profit margin and return on capital employed; financial risk is assessed using interest cover and various measures of gearing. In some contexts performance is judged against an absolute benchmark. For example, loan covenant restrictions may focus on a maximum gearing level or a minimum level of interest cover (or both). Executive compensation schemes may, in part, be based on achieving a particular level of profitability (e.g. return on assets, or return on equity). In other decision contexts, such as investment decisions made by investors, the relative performance of companies may be more relevant (i.e. company rankings). The two studies investigated the impact that operating lease capitalisation would have on absolute performance measures by comparing the differences between pre- and post-capitalisation ratios. The impact on relative performance was assessed by measuring the correlation between pre- and post-capitalisation ratios. Results for three of the nine ratios investigated, operating profit margin, return on capital employed (ROCE) and net debt to equity gearing ratio, are summarised in Table 2.

\section{< Table 2 about here >}

For the earlier cross-sectoral study (Panel A), operating profit margin and gearing increased significantly in all three sectors and overall. For example, the mean operating profit margin increased from $8.8 \%$ to $9.8 \%$, overall and from $8.1 \%$ to $10.1 \%$ in the services sector. Gearing increased from $20 \%$ to $72 \%$, overall and from $24 \%$ to $141 \%$ in the services sector. The effect of operating lease capitalisation on ROCE was small and not statistically significant. Rank correlations for profit margin and ROCE were quite high overall, at 0.953 and 0.992 respectively 
and only slightly lower in services. However, the correlation for gearing was lower overall (0.738) and much lower in services (0.534). Thus, capitalisation of operating leases would have a major impact on absolute performance ratio measures, and relative company ranking of financial risk (gearing) would change significantly.

The high use of operating leases in the retail sector is reflected in the changes in performance ratios (Panel B). The changes in all three ratios are economically and statistically significant, with just one exception, the mean measure for ROCE in food retailing. For example, over all retailers, the mean operating margin increases from $6.6 \%$ to $10.0 \%$ and gearing increases dramatically from $12 \%$ to $285 \%$. Intra-sector and sub-sector company rankings are also affected, with rank correlations of $0.871,0.894$ and 0.172 for operating margin, ROCE and gearing respectively. Thus, operating lease capitalisation in the retail sector would affect both absolute and relative performance measures, especially measures of financial risk.

A major assumption in the above estimates, somewhat unrealistic in the light of prior evidence, is that company management will not take any steps to mitigate the effect of capitalisation. Rather extremely, they might change their asset financing policies away from leasing, but this may not be possible, for example in obtaining access to 'land and buildings' assets. Alternatively, they might seek to modify lease contract terms to minimise the impact of capitalisation as illustrated by their switch from finance to operating lease contracts in response to the introduction of SSAP21 (Figure 1). Based on the current G4+1 proposals, a possible route focuses on the treatment of break clauses or renewable leases. A lease contract could include a break clause or could be written for a fairly short primary rental period with an option to renew the lease. Under the G4+1 proposals, the exercise of renewal options 'should not generally be anticipated' except where the fixed non-cancellable term is clearly unrepresentative of the period that the lessee is compelled to use the property (ASB, 1999a, pp. 90-91). Thus, one way to mitigate the impact of lease capitalisation would be to use break clauses, or shorter primary lease periods (much shorter than current practice on 'land and buildings' contracts) with options to renew for further short periods.

Goodacre (2001) reports estimates based on the fairly radical assumptions that all lease contracts (i.e., both 'other' and 'land and buildings' categories) could be negotiated to have a maximum term of 5 years, and that the value of the renewal option/break clause will be small and so can be ignored. ${ }^{7}$ Even under these assumptions, operating lease assets and liabilities would remain a substantial feature on retail companies' balance sheets. The mean total operating lease liability estimates are $£ 94 \mathrm{~m}$ (food retailers), $£ 77 \mathrm{~m}$ (general retailers) and $£ 80 \mathrm{~m}$ (all); the long-term element of these liabilities represents $37 \%, 128 \%$ and $82 \%$ of on-balance sheet debt, respectively. Overall, reported operating lease assets would represent approximately $11 \%$ of total assets. The impact on profit would also be slightly reduced but, across the retail sector overall, operating profit would still increase by about $9 \%$ and profit after tax would decrease by about $4 \%$; the impact on general retailers would continue to be slightly greater than on food retailers.

These reductions in operating lease assets and liabilities reduce the impact on performance ratios, but the pattern and (statistical) significance of the changes are almost identical to the results based on current lease terms. Correlations between pre- and post-capitalisation ratios, for the retail sector as a whole, are $0.976,0.987$ and 0.495 for operating margin, ROCE and gearing respectively. While these are higher than those reported in Table 2, the low correlation for gearing implies major changes in the ranking of companies' financial risk characteristics. The situation of maximum 5-year lease contracts modelled is obviously quite extreme and may not be realistic for many contracts. However, other 'opportunities' for mitigating the impact may be available (e.g. the use of contingent rental contracts?). The results suggest that, in the retail sector, lease capitalisation will probably have a fairly major impact on published financial statements and on performance ratios, even if company managers take steps to minimise the impact. 
Overall, there is considerable evidence that operating leases are important and that their capitalisation on balance-sheet is likely to affect both absolute measures of performance ratios and the relative ranking of companies.

\section{Does it really matter?}

Does it really matter whether leases are recognised as assets and liabilities on a company's balance sheet? Finance leases are already on the balance sheet, and some details of operating leases are disclosed by way of a footnote to the balance sheet, so users already have a reasonable amount of lease information. It does matter if the changes brought about by capitalisation of operating leases change the behaviour of any of the interested parties. For example, will investors behave differently if the leases are on the balance sheet and the profit and loss account changes as described above? Might bank, or other, lenders be willing to lend less money to the company or change the terms of loans (e.g. interest rate, loan covenant restrictions, loan term)? Might company managers change the way they operate by buying, or constructing, the asset instead of leasing, or might they try to re-negotiate the terms of lease contracts (e.g. lease period, contingent elements, break clauses, renewal options etc)? Might they change the mix of debt and equity in the capital structure?

For external users of financial statements, lease capitalisation has the potential to convey new, valuable, information about the risks and/or rewards of their relationship with the company. However, this can only happen if the information is not already available to the users, or if they can more fully appreciate the meaning of the information in its newly recognised form. If users are 'efficient' information processors (as assumed in the so-called efficient markets hypothesis) then the capitalisation of operating leases is unlikely to convey any significant new information. Users will already appreciate the meaning and significance of operating leases from the footnotes and/or other information sources. So, what is the evidence on users' informational efficiency?

The evidence on users' processing of lease accounting information is somewhat conflicting. For example, an experimental approach was used by Abdel-khalik (1981) to explore the alternative accounting methods for leases (capitalisation versus footnote-only disclosure) using a range of interested participants. He found that external users (equity and bond investment analysts, and bank loan officers) expressed a preference for a company that reported the leases in a footnote over an identical company that capitalised leases on-balance sheet. Wilkins and Zimmer (1983a) and Wilkins (1984) used Singapore-based bank loan officers as subjects in a similar experiment and found that the subjects' decisions were affected by levels of leverage but not by the method of accounting. In a related study, the behaviour of investment analysts was affected by the method of accounting (Wilkins and Zimmer, 1983b). Similarly, Munter and Ratcliffe (1983) found that investment managers' decisions were affected by lease accounting methods. Gopalakrishnan and Parkash (1996) used a survey method to identify that both lenders and managers/preparers are more likely to consider recognised (on-balance sheet) lease obligations as equivalent to debt than disclosed (off-balance sheet) obligations. They also noted that lenders are more likely than managers/preparers to regard disclosed obligations as debt. Breton and Taffler (1995) conducted a laboratory experiment using UK investment analysts to investigate their response to nine forms of creative accounting, one of which was non-capitalised leases. In general, the analysts did not make adjustments when calculating familiar financial ratios. On balance, the evidence suggests that some individual users do appear to be influenced by whether the information is recognised in the financial statements or merely disclosed in the footnotes to the accounts.

On the other hand, there is both general and lease-specific evidence that users in aggregate (i.e., the stock market) are not misled by such presentational issues. In particular, there is quite strong evidence for both the UK (Beattie, Goodacre and Thomson, 2000b) and the US (Ely, 1995; Imhoff, Lipe and Wright, 1993) that the market already incorporates footnote operating lease disclosures in its assessment of equity risk. ${ }^{8}$ However, the research design adopted in these studies is unable to determine whether or not the extent of the market's adjustment to equity risk is 'correct'. Further, 
there is evidence that, at least some, investment analysts and credit rating agencies recast financial statements by calculating the assets and liabilities implicit in off-balance sheet operating leases (e.g., Dresdner Kleinwort Benson, 1998).

The general evidence that markets are informationally efficient suggests that any changes in reported performance resulting from the accounting changes are probably already impounded in stock market prices. However, the evidence that individual users (e.g., bank-lenders, investment analysts) may not be informationally efficient suggests that company capital-raising may be affected by the proposed accounting changes. Further, there is strong evidence that company managers do not believe that users, in aggregate or individually, process information efficiently (e.g. Mayer-Sommer, 1979; Abdel-khalik, 1981; Taylor and Turley, 1985). This suggests that managers' decisions will be affected by the expected change in performance measures if all leases are required to be recognised on lessees' balance sheets, as a result of information inductance (Prakash and Rappaport, 1977). That is, company managers expect users to respond differently to the new reporting methods so the managers are likely to behave as if the markets are 'inefficient'.

\section{Leasing and capital structure}

Survey results suggest that managers believe that overall 'debt capacity' can be increased by using leases; (UK: Drury and Braund, 1990; US: Bathala and Mukherjee, 1995; Gopalakrishnan and Parkash, 1996). Further, regression-based analyses confirm that companies behave as if lease finance is complementary to (US: Ang and Peterson, 1984), or only a partial substitute for debt finance (US: Marston and Harris, 1988; Krishnan and Moyer, 1994; UK: Adedeji and Stapleton, 1996; Beattie, Goodacre and Thomson, 2000a; Belgium: Deloof and Verschueren, 1999); in both situations the use of leases allows an increase in overall 'borrowing'. In the UK, Adedeji and Stapleton (1996) estimated that $£ 1$ of finance leasing displaced about $£ 0.55$ of debt. Most studies have investigated only finance leases, but Beattie, Goodacre and Thomson (2000a) found that $£ 1$ of leases (mainly operating leases) displaced approximately $£ 0.23$ of debt for UK companies. Thus, operating leases appear to absorb less debt capacity than finance leases, consistent with the argument that lessors bear risks, particularly in operating lease contracts, that would be borne by the lessee company if debt finance were used.

The inclusion of operating leases on companies' balance sheets has the potential to change lenders and/or company managers' perception of 'debt capacity'. In turn, this might affect companies' overall capital structure policies. The requirement to capitalise finance leases following the introduction of the original lease accounting standards seems to have had such an impact. Evidence of changes in capital structure was found in the US (Abdel-khalik, 1981) and in Australia (Godfrey and Warren, 1995). Also for the US, Imhoff and Thomas (1988) document a systematic substitution from finance leases to operating leases and non-lease sources of finance; this suggests that re-negotiation of lease contracts may be a relatively low-cost alternative for mitigating the financial statement effects. In addition, lessees appeared to reduce book leverage by increasing equity and reducing conventional debt. In the UK, Garrod (1989) found that managers reacted to the standard by reducing their non-lease debt prior to their first disclosure of lease information following the introduction of SSAP21.

\section{Implications}

If, in future, all leases are treated similarly (i.e., are included on the lessee's balance sheet) this might change company managers attitudes to leasing. First, company managers might reduce their use of leasing (for example, because of concerns about users' perception of the company's closeness to its 'borrowing capacity'). This might encourage greater involvement in the construction and ownership of property. In this approach the company owner benefits from rising property values, but also takes on the risk of falls in value. If an interest-only loan is used to fund the purchase, gearing will remain high until the loan is repaid, though a 'repayment' mortgage 
would more closely mirror the gearing under a lease contract. However, the cost of the freehold is likely to be higher than the present value of lease rentals so gearing will be higher. Also increased owner-occupation runs counter to the trend towards outsourcing all but core activities. Further, the option is not always available since the relevant properties or sites may already be under long-term ownership by property companies or financial institutions.

Second, managers might prefer to continue with the leasing alternative while seeking lease contract terms that minimise the balance sheet impact of lease capitalisation. This could take various forms including increased use of break clause, or renewable shorter-term leases or perhaps the greater use of contingent rental agreements.

Ringer and Unerman (2000) discuss the short-term implications of this change in management attitude to leasing. They suggest that tenants whose leases expire are likely to negotiate new leases with greater flexibility and shorter terms. This may result in increased market rents to compensate landlords for the reduction in the security that long-term leases currently offer. The impact of such changes on lessee and lessor will depend on their relative bargaining positions. In prime sites where there is a shortage in supply, landlords will be in a strong position to demand higher rents for shorter leases. In sectors or regions where supply exceeds demand, changes in market rents are unlikely to fully reflect the increased risk suffered by the landlord. The authors also suggest that the sale and leaseback market will change with prospective landlords probably needing to offer more flexible leaseback terms, including regular tenant break options. The current occupiers will often have to accept either a lower sale value or higher rents to compensate the landlord. Also, forthcoming break clauses may be used by tenants to renegotiate lease conditions in areas where there is excess supply of property.

Obviously, the use of effectively shorter lease terms would not suit all circumstances. However, it is consistent with the trend towards lessees seeking shorter leases for purely commercial reasons, mainly reflecting lessees' need for greater flexibility in choosing and changing locations of retail outlets, for example (Nelson, 1999; BPF/IPD, 1999; Crosby, Gibson and Murdoch, 2000; Crosby, Gibson and Oughton, 2001). These renewable short contracts are likely to shift risks from lessees to lessors since, for example, the lessor will now bear the risk that the lessee will not exercise the option to renew (or will exercise a break option). This is most likely to happen when the attractiveness of the asset has reduced for some reason. When this is a general 'decline' in the future worth of the asset, rather than lessee-specific, then a significant cost (loss of value, difficulty in obtaining a new lessee or disposing of the asset) will be borne by the lessor. Thus, the major implication of the changes in company management behaviour is that lessors are likely to be under pressure to bear greater risks than previously.

Finally, what are the implications for the future of real estate leasing? Does the increased risk mean that investors/lessors will be less enthusiastic to invest in property? This seems unlikely, though investors in future will perhaps need a greater focus on risk management. Prior research provides evidence of plausible and rational links between returns and risk, suggesting that in the longer-term, the increased risk is likely to be compensated by increased return. Also, while increased residual value risk and transaction costs are likely to increase required yields, shorter lease contracts have the countervailing benefit of reducing default risk. ${ }^{10}$ Overall, it seems likely that the rationales for the existence of commercial real estate leasing (see, for example, Benjamin, de la Torre and Musumeci, 1998) will continue, even expand; market imperfections are likely to allow both landlord and tenants to continue to benefit from leasing. 


\section{Endnotes}

${ }^{1}$ Until its dissolution in 2001, the G4+1 consisted of members from the accounting standard-setting bodies of Australia, Canada, New Zealand, the UK, the US and the International Accounting Standards Committee (IASC). The group represented an informal attempt to co-operate over developments so as to ensure similar accounting standards in each jurisdiction. This role has now been subsumed by the newlyconstituted International Accounting Standards Board.

2 Since December 1999, all the G4+1 organisations have published the discussion paper in their own jurisdictions but further progress on accounting standards is likely to be slow. The next stage in the procedure would be to issue a Financial Reporting Exposure Draft (FRED) containing detailed proposals for comments. This would be followed, perhaps a year or so later, by an accounting standard. However, even in the UK where there has been strong commitment to the project, the ASB on its web-site (August 2002) reports that it 'is considering the issues raised by respondents to the (Discussion) Paper, and is continuing to exchange views and information with other members of the G4+1. Due to the complexity of the issues involved, it is expected to take some time to fully consider them. Therefore, it is unlikely that a Financial Reporting Exposure Draft will be published in the near future.' Recent developments in attempts to harmonise accounting standards internationally have also slowed down the process. The difficulties in achieving consensus on changes in lease accounting mean that it is not a politically attractive topic for early consideration by an International Accounting Standards Board seeking globally-acceptable accounting standards. However, the difficulties are likely to cause delay rather than abandonment; the issue will not go away as the standard setters fully recognise the need for change. Indeed the lease accounting standard in the US was voted the 'worst accounting standard' by a group of leading accountants (Reither, 1998).

3 This treatment is theoretically sound since a nominal interest rate (which incorporates the market's inflation expectations) is used to discount the minimum lease rentals.

${ }^{4}$ In reality, the tax charged in the profit and loss account will be lower in the early years of the lease, reflecting the lower reported profit before tax, and higher in the later years. The difference between tax paid and charged is accommodated by adjustments to deferred tax. Further, the Inland Revenue is increasingly arguing that profit for tax purposes should generally follow accounting rules. Thus, it is entirely possible that the tax treatment of 'operating' lease rentals may change should the G4+1 proposals be adopted.

${ }^{5}$ Comparisons between the two studies should be undertaken with caution in view of the different time periods, and the different assumptions concerning discount rates: 10\% in Beattie Edwards and Goodacre (1998) compared with $8.5 \%$ in Goodacre (2001).

${ }^{6}$ Beattie, Edwards and Goodacre (1998) did not separately report the impact on profit.

${ }^{7}$ For simplicity, any increase in lease rental required to compensate for the lessor taking on additional residual value risk is also ignored. Thus, lessees' operating lease assets and liabilities are likely to be understated.

8 By contrast, Gallery and Imhoff (1998) found no evidence that Australian stock market investors incorporate footnote operating lease disclosures in their assessment of equity risk.

${ }^{9}$ For example, company managers appear to have reacted in this way to a requirement to report inflationadjusted income numbers in the US (Odaiyappa and Nainar, 1992).

${ }^{10}$ Schallheim, Johnson, Lease and McConnell (1987) empirically examine the determinants of lease yields for a sample of (non-real estate) lease contracts. They confirm that lease yields are related to risk-free bond yields, and proxies for residual value risk, transaction and information costs associated with the lease, as well as lessee default risk. With shorter, renewable (or break) real estate lease contracts, residual value risk will increase and transaction costs are likely to represent a relatively larger part of total costs. If the broad thrust of Schallheim et al's results were to apply to real estate, this suggests an increase in yields. Grenadier (1996) models credit spread on leases subject to default risk and identifies that the term structure of spreads is upward-sloping; i.e. the premium that a tenant must pay relative to a 'riskless tenant' will be less for shorter leases. 


\section{References}

Abdel-khalik, A.R. (1981) The Economic Effects on Lessees of FASB Statement No. 13, Accounting for Leases, Financial Accounting Standards Board, Stamford, CT.

Adedeji, A. and Stapleton, R.C. (1996) Leases, debt and taxable capacity, Applied Financial Economics, 6(1), 71-83.

Ang, J. and Peterson, P.P. (1984) The leasing puzzle, Journal of Finance, 39(4), 1055-1065.

ASB (1999a) Leases: Implementation of a New Approach, Discussion Paper, Accounting Standards Board, London.

ASB (1999b) Statement of Principles for Financial Reporting, Accounting Standards Board, London.

ASC (1984) Accounting for Leases and Hire Purchase Contracts, Statement of Standard Accounting Practice No. 21, Accounting Standards Committee, London.

Bathala, C.T. and Mukherjee, T.K. (1995) A survey of leasing in small firms, Journal of Small Business Finance, 4(2/3), 113-127.

Beattie, V.A., Edwards, K. and Goodacre, A. (1998) The impact of constructive operating lease capitalisation on key accounting ratios, Accounting and Business Research, 28(4), 233254.

Beattie, V.A., Goodacre, A. and Thomson, S. (2000a) Operating leases and the assessment of lease-debt substitutability, Journal of Banking and Finance, 24(3), 427-470.

Beattie, V.A., Goodacre, A. and Thomson, S. (2000b) Recognition versus disclosure: an investigation of the impact on equity risk using UK operating lease disclosures, Journal of Business Finance and Accounting, 27(9\&10), 1185-1224.

Benjamin, J.D., de la Torre, C. and Musumeci, J. (1998) Rationales for real estate leasing versus owning, Journal of Real Estate Research, 15(3), 223-237.

BPF/IPD (1999) Annual Lease Review 1999, British Property Federation/ Investment Property Databank, London.

Breton, G. and Taffler, R.J. (1995) Creative accounting and investment analyst response, Accounting and Business Research, 25(98), 81-92.

Crosby, N., Gibson, V.A. and Murdoch, S. (2000) 'Office lease lengths', paper presented at the RICS Cutting Edge Conference, London.

Crosby, N., Gibson, V.A. and Oughton, M. (2001) 'Lease structures terms and lengths - a survey of corporate occupiers', paper presented at the RICS Cutting Edge Conference, Oxford.

Deloof, M. and Verscheuren, I. (1999) Are leases and debt substitutes? Evidence from Belgian firms, Financial Management, 28(2), 91-95.

Dresdner Kleinwort Benson (1998) Operating leases: the retail house of cards, Dresdner Kleinwort Benson Research, London.

Drury, C. and Braund, S. (1990) The leasing decision: a comparison of theory and practice, Accounting and Business Research, 20(79), 179-191.

Edwards, K.E. (1997) 'The impact of constructive operating lease capitalisation on key accounting ratios', MSc thesis, University of Stirling.

Ely, K.M. (1995) Operating lease accounting and the market's assessment of equity risk, Journal of Accounting Research, 33(2), 397-415.

Gallery, G. and Imhoff, E.A. (1998) 'Disclosure versus recognition: some evidence from the Australian capital market regarding off-balance sheet leasing', paper presented at the University of Melbourne, Research Seminar Series. 
Garrod, N. (1989) Regulation and response: the case of lease disclosure in the UK, Research in Accounting Regulation, 3, 69-92.

Godfrey, J.M. and Warren. S.M. (1995) Lessee reactions to regulation of accounting for leases, Abacus, 31(2), 201-228.

Goodacre, A. (2001) 'The potential impact of enforced lease capitalisation in the UK retail sector', University of Stirling, Dept of Accounting, Finance and Law Discussion Paper DP 01/01.

Goodacre, A. and Beattie, V.A. (1999) Operating leases get the treatment, Professional Investor, October, 24-27.

Gopalakrishnan, V. and Parkash, M. (1996) The debt-equivalency of recognized vs. disclosed obligations: an examination of borrower and lender perceptions, Research in Accounting Regulation, 10, 63-77.

Grenadier, S.R. (1996) Leasing and credit risk, Journal of Financial Economics, 42(3), 333-364.

Imhoff, E.A. and Thomas, J.K. (1988) Economic consequences of accounting standards: the lease disclosure rule change, Journal of Accounting and Economics, 10(4), 277-310.

Imhoff, E.A., Lipe, R.C. and Wright, D.W. (1991) Operating leases: impact of constructive capitalization, Accounting Horizons, 5(1), 51-63.

Imhoff, E.A., Lipe, R.C. and Wright, D.W. (1993) The effects of recognition versus disclosure on shareholder risk and executive compensation, Journal of Accounting, Auditing and Finance, 8(4), 335-368.

Imhoff, E.A., Lipe, R.C. and Wright, D.W. (1997) Operating leases: income effects of constructive capitalization, Accounting Horizons, 11(2), 12-32.

Investment Property Forum (1999) Proposed capitalisation of operating leases - what impact on the UK property market?, Forum Review, Issue No. 3 October, 2-3.

Krishnan, V.S. and Moyer, R.C. (1994) Bankruptcy costs and the financial leasing decision, Financial Management, 23(2), 31-42.

Marston, F. and Harris, R.S. (1988) Substitutability of leases and debt in corporate capital structures, Journal of Accounting, Auditing and Finance, 3(2), 147-164.

Mayer-Sommer, A.P. (1979) Understanding and acceptance of the efficient markets hypothesis and its accounting implications, Accounting Review, 54(1), 88-106.

McGregor, W. (1996) Accounting for Leases: A New Approach, Financial Accounting Standards Board, Stamford, CT.

Munter, P. and Ratcliffe, T.A. (1983) An assessment of user reactions to lease accounting disclosure, Journal of Accounting, Auditing and Finance, 6(2), 108-114.

Nelson, F. (1999) Trouble in store for high street retailers, The Times, 4 December, 31.

Odaiyappa, R. and Nainar, S.M.K. (1992) Economic consequences of SFAS No 33 - an insidertrading perspective, Accounting Review, 67(3), 599-609.

Prakash, P. and Rappaport, A. (1977) Information inductance and its significance for accounting, Accounting, Organisations and Society, 2(1), 29-38.

Reither, C.L. (1998) What are the best and the worst accounting standards?, Accounting Horizons, 12(3), 283-292.

Ringer, M. \& Unerman, J. (2000) Hidden gearing, Accountancy, June, 104-105.

Schallheim, J.S., Johnson, R.E., Lease, R.C. and McConnell, J.J. (1987) The determinants of yields on financial leasing contracts, Journal of Financial Economics, 19(1), 45-67.

Taylor, P. and Turley, S. (1985) The views of management on accounting for leases, Accounting and Business Research, 16(61), 59-67. 
Wilkins, T. (1984) A behavioural investigation of alternative methods of financing capital acquisitions and lease capitalization, Accounting and Business Research, 14(56), 359366.

Wilkins, T. and Zimmer, I. (1983a) The effect of leasing and different methods of accounting for leases on credit evaluations, Accounting Review, 58(4), 749-764.

Wilkins, T. and Zimmer, I. (1983b) The effect of alternative methods of accounting for leases an experimental study, Abacus, 19(1), 64-75. 
Figure 1: The growing use of operating leases by quoted companies

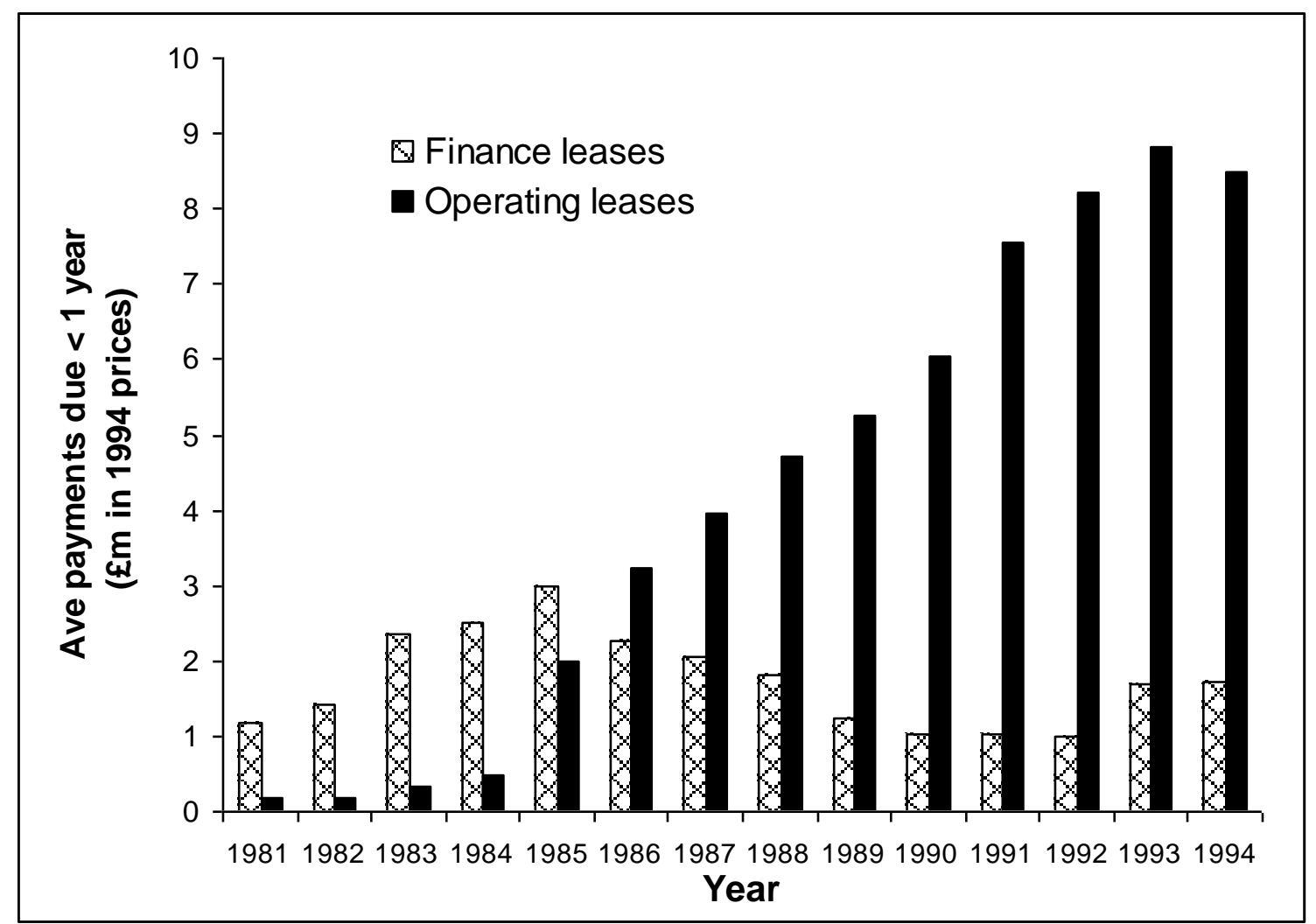

Source: Goodacre and Beattie (1999) 
Figure 2: Operating leases and debt levels

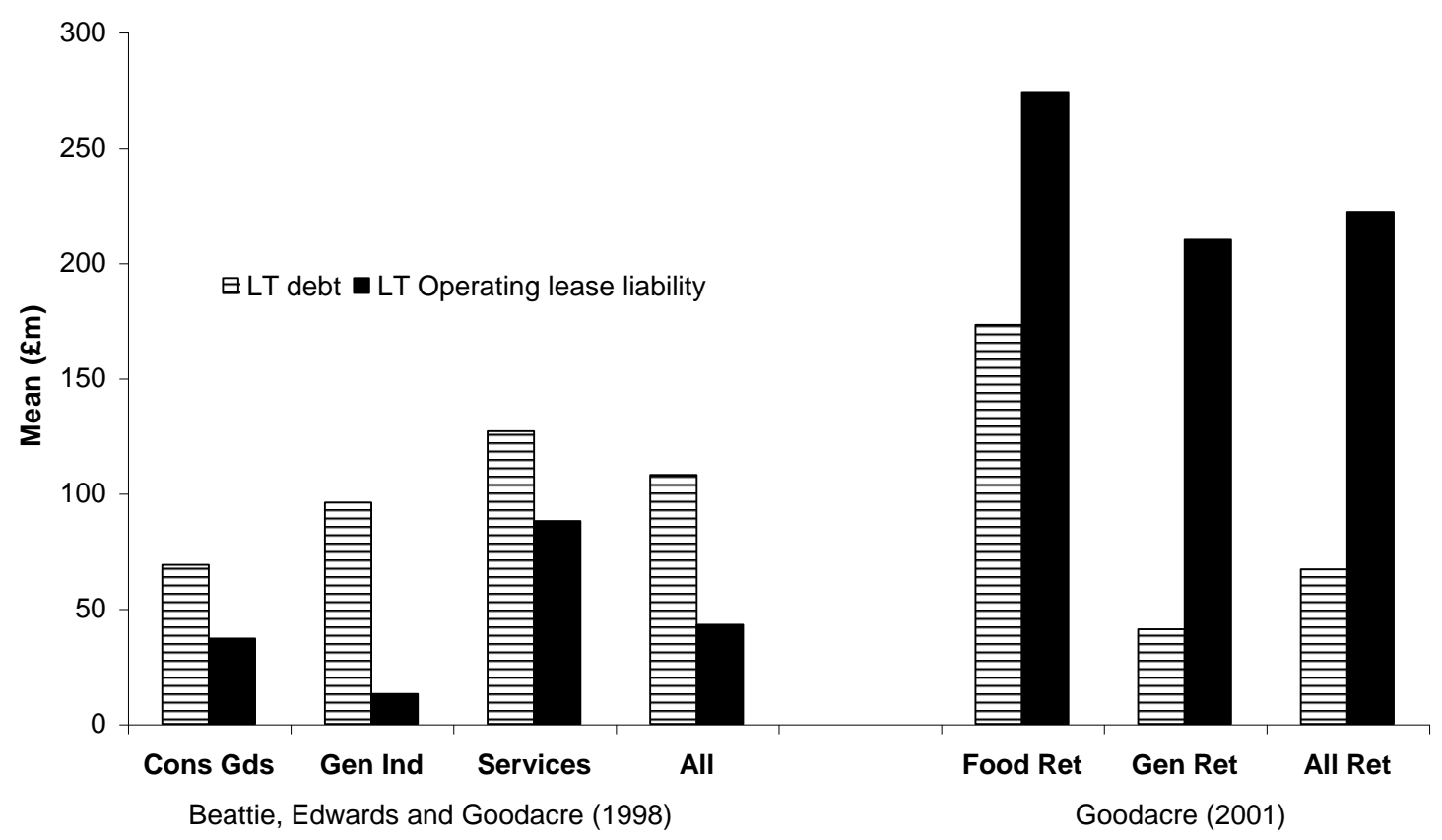


Figure 3: Long-term operating leases as a percentage of long-term debt

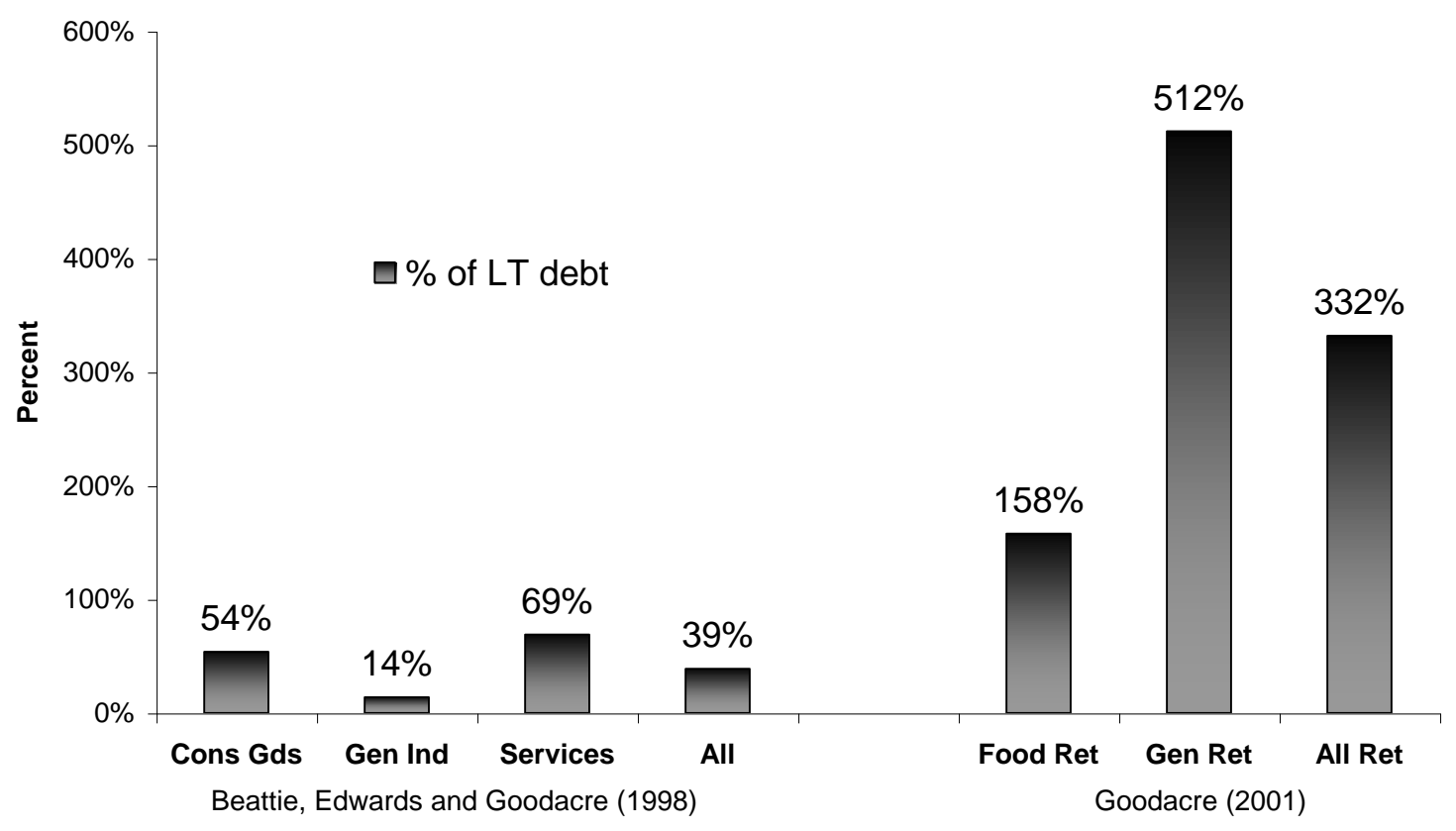




\section{Table 1: Illustration of the financial statement impact of lease capitalisation}

Base assumptions

At 31 December 2000, a company has short-term assets of $£ 1,400 \mathrm{k}$ and long-term debt of $£ 400 \mathrm{k}$ (interest payable of $£ 30 \mathrm{k} \mathrm{pa}$ ), giving equity shareholders funds of $£ 1,000 \mathrm{k}$. For simplicity, assume that sales (£3,000k pa) and profit before property costs (£450k pa) are constant over the five-year period, that all after-tax profits (£120k) are paid out as dividends, and that deferred taxation can be ignored.

On 31 December 2000 the company leases a retail outlet for a term of 5 years with lease rentals of $£ 250 \mathrm{k}$ payable annually in arrears. The present value of the lease rentals is $£ 1,000 \mathrm{k}$ (implicit interest rate of $7.93 \%$ ).

PANEL A

Balance Sheet as at 31 December

Assets

Leased property: net book value

Other (short-term) assets

Total assets

Liabilities

Debt: long-term

Lease liability: short-term

Lease liability: long-term

Lease liability: total

Total liabilities

Total net assets

\section{Shareholders funds}

Share capital

Retained profit

Lease impact on profit (cumulative)

Net debt/equity ratio (\%)

PANEL B

Profit and loss for year to 31 Dec

Profit before property costs

Operating lease rental (OLR)

EBITDA

Depreciation

Operating profit (EBIT)

Interest

Interest element of lease rental

Profit before tax

Tax paid

Profit after tax

Dividends

Retained profit

Operating margin (\%)

Return on capital employed (\%)

\begin{tabular}{rrrrrrr}
$\begin{array}{r}\text { Operating } \\
\text { lease }\end{array}$ & \multicolumn{7}{c}{$\begin{array}{c}\text { Capitalised lease } \\
\text { (all figures are } £ 000 \text { s) }\end{array}$} \\
\cline { 2 - 8 } $\mathbf{2 0 0 0}$ & $\mathbf{2 0 0 0}$ & $\mathbf{2 0 0 1}$ & $\mathbf{2 0 0 2}$ & $\mathbf{2 0 0 3}$ & $\mathbf{2 0 0 4}$ & $\mathbf{2 0 0 5}$ \\
& & & & & & \\
0 & 1000 & 800 & 600 & 400 & 200 & 0 \\
1400 & 1400 & 1400 & 1400 & 1400 & 1400 & 1400 \\
1400 & 2400 & 2200 & 2000 & 1800 & 1600 & 1400
\end{tabular}

\begin{tabular}{|c|c|c|c|c|c|c|}
\hline 400 & 400 & 400 & 400 & 400 & 400 & 400 \\
\hline 0 & 171 & 184 & 199 & 215 & 231 & 0 \\
\hline 0 & 829 & 645 & 446 & 231 & 0 & 0 \\
\hline 0 & 1000 & 829 & 645 & 446 & 231 & $\overrightarrow{0}$ \\
\hline$\underline{400}$ & $\underline{1400}$ & $\underline{1229}$ & 1045 & $\underline{846}$ & 631 & $\underline{400}$ \\
\hline 1000 & 1000 & 971 & 955 & 954 & 969 & 1000 \\
\hline
\end{tabular}

$\begin{array}{rrrrrrr}500 & 500 & 500 & 500 & 500 & 500 & 500 \\ 500 & 500 & 500 & 500 & 500 & 500 & 500 \\ \underline{0} & \underline{0} & \underline{\underline{-29}} & \underline{\underline{-45}} & \underline{\underline{-46}} & \underline{\underline{-31}} & \underline{0} \\ \underline{\underline{1000}} & \underline{\underline{1000}} & \underline{\underline{971}} & \underline{\underline{955}} & \underline{\underline{954}} & \underline{\underline{969}} & \underline{\underline{1000}} \\ 40 & 140 & 127 & 109 & 89 & 65 & 40\end{array}$

\section{1}

Impact

in 2001

$\begin{array}{lll}2001 & 2002 & 2003\end{array}$

2004

2005

$\begin{array}{rrrrrrr}450 & 0 & 450 & 450 & 450 & 450 & 450 \\ \underline{-250} & \underline{250} & \underline{0} & \underline{0} & \underline{0} & \underline{0} & \underline{0} \\ 200 & 250 & 450 & 450 & 450 & 450 & 450 \\ \underline{0} & \underline{-200} & \underline{-200} & \underline{-200} & \underline{-200} & \underline{-200} & \underline{-200} \\ 200 & 50 & 250 & 250 & 250 & 250 & 250 \\ -30 & 0 & -30 & -30 & -30 & -30 & -30 \\ \underline{0} & \underline{-79} & \underline{-79} & \underline{-66} & \underline{-51} & \underline{-35} & \underline{-19} \\ 170 & -29 & 141 & 154 & 169 & 185 & 201 \\ \underline{-50} & \underline{0} & \underline{-50} & \underline{-50} & \underline{-50} & \underline{-50} & \underline{-50} \\ 120 & -29 & 91 & 104 & 119 & 135 & 151 \\ \underline{120} & \underline{0} & \underline{120} & \underline{120} & \underline{120} & \underline{120} & \underline{120} \\ \underline{0} & \underline{\underline{-29}} & \underline{\underline{-29}} & \underline{\underline{-16}} & \underline{\underline{-1}} & \underline{\underline{15}} & \underline{\underline{31}}\end{array}$

8.3

12.4
8.3

8.3

18.3
8.3

17.9

Note: Return on capital employed is defined as EBIT/(Total assets less current liabilities) 
Table 2: Changes in ratios following operating lease capitalisation

\begin{tabular}{|c|c|c|c|c|c|c|c|c|c|c|}
\hline \multicolumn{11}{|c|}{ Panel A: Random sample of 232 UK companies in 1994 (Beattie, Edwards and Goodacre, 1998) ${ }^{1}$} \\
\hline & & \multicolumn{3}{|c|}{$\underline{\text { Consumer Goods }}$} & \multicolumn{2}{|c|}{ General Industrial } & \multicolumn{2}{|c|}{ Services } & \multicolumn{2}{|c|}{ All sectors } \\
\hline & & pre & post & & pre & post & pre & post & pre & post \\
\hline Operating & Mean & 10.0 & 10.7 & ** & 7.1 & $7.7^{* *}$ & 8.1 & $10.1^{* *}$ & 8.8 & 9.8 ** \\
\hline \multirow[t]{2}{*}{ margin (\%) } & Median & 9.2 & 9.8 & ** & 7.7 & $8.5^{* *}$ & 6.7 & $9.5 * *$ & 8.0 & $9.0^{* *}$ \\
\hline & Correlation $^{2}$ & & 0.988 & & & 0.985 & & 0.903 & & 0.953 \\
\hline Return on capital & Mean & 10.5 & 11.1 & & 14.8 & 14.7 & 16.2 & 15.9 & 14.6 & 14.5 \\
\hline \multirow[t]{2}{*}{ employed (\%) } & Median & 13.9 & 14.2 & & 15.5 & 15.6 & 17.0 & 16.2 & 15.6 & 15.6 \\
\hline & Correlation $^{2}$ & & 0.999 & & & 0.997 & & 0.982 & & 0.992 \\
\hline Gearing (net debt & Mean & 22.0 & 45.0 & $* *$ & 14.0 & $32.0^{* *}$ & 24.0 & $141.0^{* *}$ & 20.0 & $72.0^{* *}$ \\
\hline \multirow[t]{2}{*}{ to equity) (\%) } & Median & 12.0 & 29.0 & $* *$ & 15.0 & $29.0^{* *}$ & 19.0 & $56.0^{* *}$ & 14.0 & $38.0^{* *}$ \\
\hline & Correlation $^{2}$ & & 0.837 & & & 0.927 & & 0.534 & & 0.738 \\
\hline
\end{tabular}

Panel B: All UK retail companies in 1999 (Goodacre, 2001)

\begin{tabular}{|c|c|c|c|c|c|c|c|}
\hline & & \multicolumn{2}{|c|}{ Food retailers } & \multicolumn{2}{|c|}{$\underline{\text { General retailers }}$} & \multicolumn{2}{|c|}{ All retailers } \\
\hline & & pre & post & pre & post & pre & post \\
\hline Operating & Mean $^{3}$ & 1.5 & $4.2^{* *}$ & 7.7 & $11.3^{* *}$ & 6.6 & $10.0^{* *}$ \\
\hline \multirow[t]{2}{*}{ margin (\%) } & Median & 4.3 & $5.7^{* *}$ & 8.1 & $11.5^{* *}$ & 7.7 & $10.7^{* *}$ \\
\hline & Correlation $^{2}$ & & 0.816 & & 0.864 & & 0.871 \\
\hline Return on capital & Mean $^{3}$ & 14.2 & 12.8 & 24.7 & 15.9 ** & 22.8 & $15.3^{* *}$ \\
\hline \multirow[t]{2}{*}{ employed (\%) } & Median & 17.3 & $14.7^{*}$ & 21.1 & $15.2^{* *}$ & 18.9 & $15.2^{* *}$ \\
\hline & Correlation $^{2}$ & & 0.827 & & 0.901 & & 0.894 \\
\hline Gearing (net debt & Mean $^{3}$ & 18.3 & $149.0^{* *}$ & 10.6 & $320.6^{* *}$ & 12.2 & $285.4^{* *}$ \\
\hline \multirow[t]{2}{*}{ to equity) (\%) } & Median & 15.2 & $111.3^{* *}$ & 16.6 & $156.7^{* *}$ & 15.9 & $153.6^{* \star}$ \\
\hline & Correlation $^{2}$ & & 0.294 & & 0.151 & & 0.172 \\
\hline
\end{tabular}

Notes

1. Median figures were sourced from Edwards (1997)

2. Spearman rank correlation between pre- and post-capitalisation ratios

3. Mean ratios reported here for the first time

4. $* *(*)=$ significance at $1 \%(5 \%)$ level of two-tailed Wilcoxon signed ranks test of difference in medians, or two-tailed t-test of difference between means. 